\title{
Toxicity of brazilian medicinal plant extracts on Macrobrachium amazonicum
}

\author{
Tainára Cunha Gemaque
}

Aquaculture Laboratory LAQUA (mariculture sector), Universidade Federal de Minas Gerais - UFMG, Av. Pres. Antônio Carlos 6627, Pampulha, Belo Horizonte - Minas Gerais 31270-901, Brazil.

Tel: 55-37-98803-2898 E-mail: tainarapesca@gmail.com

ORCID: 0000-0001-7348-6505

Sérgio Rodrigues da Silva

Aquaculture Laboratory LAQUA (mariculture sector), Universidade Federal de Minas Gerais - UFMG, Av. Pres. Antônio Carlos 6627, Pampulha, Belo Horizonte - Minas Gerais 31270-901, Brazil.

Tel: 55-31-9289-9295 E-mail: srsbio@gmail.com

ORCID: 0000-0003-3091-6354

\section{Daniele Salgueiro de Melo}

Aquaculture Laboratory LAQUA (mariculture sector), Universidade Federal de Minas Gerais - UFMG, Av. Pres. Antônio Carlos 6627, Pampulha, Belo Horizonte - Minas Gerais 31270-901, Brazil.

Tel: 55-37-98803-2898 E-mail: danielesalgueiro08@hotmail.com

ORCID: 0000-0002-3525-8613

Daniel Pereira da Costa

Amapá State University - UEAP, Campus Lakes Territory, Av. Desidério Antônio Coelho 470, Sete Mangueiras, Amapá, Amapá 68950-000, Brazil.

Tel: 55-37-98817-6804 E-mail: costazootecnia@gmail.com

ORCID: 0000-0002-8261-9899 
Kleber Campos Miranda Filho (Corresponding author)

Aquaculture Laboratory (mariculture sector), Universidade Federal de Minas Gerais UFMG Av. Pres. Antônio Carlos 6627, Pampulha, Belo Horizonte - Minas Gerais 31270-901, Brazil.

Tel: 55-31-98350-5167 E-mail: kleber08@gmail.com

ORCID: 0000-000 2-3026-4491

Received: January 10, 2021

doi:10.5296/jas.v9i2.18162
Accepted: March 24, 2021 Published: April 18, 2021

URL: https://doi.org/10.5296/jas.v9i2.18162

\begin{abstract}
Medicinal plants from Amazon have been commercialized for decades, but few scientific studies prove their effectiveness and safety in use in aquaculture activities. The objective of the present study was to use the Amazon river prawn Macrobrachium amazonicum to predict the toxicity of the natural extracts of nine medicinal plants viz pariri Arrabidaea chica, muirapuama Ptychopetalum olacoides, anauerá Licania macrophylla, barbatimão Ouratea hexasperma, faveira Vatairea guianensis, sacaca Croton cajucara, jacareúba Calophyllum brasilliense, pau d'arco Tabebuia sp. and verônica Dalbergia subcymosa, in concentrations of $1,10,100,500$ and $1000 \mu \mathrm{g} / \mathrm{mL}$. The media was prepared in $0.5 \%$ dimethyl sulfoxide (DMSO) diluted with water. Ten post-larvae $(0.5 \pm 0.1 \mathrm{~g})$ were added to each triplicate and, after $24 \mathrm{~h}$, the mortalities were evaluated, with the results of median lethal concentration expressed as $\mathrm{LC}_{50}-24 \mathrm{~h}$ using the Probit statistical method. To obtain the concentrations of a common bioactive compound of plant extracts, the concentrations of flavonoids were analyzed using a methodology based on the formation of chromophores. The results of acute toxicity indicate variability in the toxic effects of medicinal plants, taking into account the concentration of total flavonoids, with the least toxic Tabebuia sp. $\left(\mathrm{LC}_{50}=758.31 \mu \mathrm{g} / \mathrm{mL}\right.$ ) and the most toxic $C$. cajucara and $V$. guianensis $\left(\mathrm{LC}_{50}=72.16\right.$ and $75.23 \mu \mathrm{g} / \mathrm{mL}$ ), respectively. The extracts demonstrated lethality against $M$. amazonicum, which predicts toxicity and warns of its use them as herbal medicines. More studies must be carried out to determine other bioactive compounds in the plant extracts used since there is an unparalleled availability of chemical diversity.
\end{abstract}

Keywords: Amazon, aquaculture, lethality, medicinal plants, post-larvae

\title{
1. Introduction
}

The use of medicinal plants is a traditional form of treatment for human use and with great potential for use in aquaculture. In Brazil, because of its rich biodiversity, many researches have been focused on natural products, from new renewable sources of energy, from biomass (biofuels), or other industrial uses, to those directed to drugs. Currently, the pharmaceutical 
industry handles high numbers worldwide, selling derivatives of medicinal plants (Albuquerque \& Hanazaki, 2006). Among the medicinal plants studied for this purpose, the following stand out:

\section{Arrabidaea chica (Pariri)}

A scandent shrub traditionally indicated to treat symptoms of inflammation. Its ethanolic extracts are chemically investigated and tested against yeasts and dermatophyte fungi (Vicentino \& Menezes, 2007).

\section{Ptychopetalum olacoides (Muirapuama)}

The indigenous tribes of Brazil use the bark and roots in infusion for many purposes as a treatment for neuromuscular disorders, cardiac and gastrointestinal asthenia acting as a muscle tonic (Velasco et al., 2008).

\section{Licania macrophylla (Anauerá)}

It is popularly known as "anauerá" or "anuera", being found mainly on the lowland margins of the lower Amazon regions. Amazon communities use the stem bark of this plant as an antibiotic in the treatment of amoebic parasites and dysentery disorders. The Licania genus is rich in bioactive compounds such as flavonoids, terpenoids, steroids, etc (Lopes et al., 2012).

Ouratea hexasperma (Barbatimão)

The Ouratea genus comprises 300 tropical species that occur mainly in South America and has been reported to be used in folk medicine for the treatment of inflammation (Rocha \& Galende, 2014).

Vatairea guianensis (Faveira)

Native to the Amazon, known as "fava bolacha" or "faveira". Its fruits, stem bark, roots, leaves and juices are used for treatment as a dermatological antifungal (Araújo, 2010).

\section{Croton cajucara (Sacaca)}

Popularly known as "Sacaca", it is a shrub with odorous leaves, common in the Amazon. In northern Brazil, the leaves and bark are used in teas, tinctures, or tablets as a hepatic-protective and antibiotic substance (Brasil, 2014).

Calophyllum brasiliense (Jacareúba)

It is of great interest in popular medicine and is used in the treatment of diabetes, and also as a healing and anti-viral substance (Carvalho et al., 2013).

Tabebuia sp. (Pau d'arco)

It is a species from the North and Northeast regions of Brazil, known as "ipê-roxo" and used in traditional medicine to contain inflammation (Carnevale et al., 2013).

Veronica officinalis (Verônica) 
Used popularly to treat hemorrhage, and as antioxidant. It has properties such as healing, antifungal, antimicrobial, anthelmintic and anti-inflammatory (Saha et al., 2013).

Toxicological studies assess the harmful effects (acute and chronic) of chemical substances on living organisms. It operates on the principle that it is based on exploring the risk of animal and human exposure to various products to be able to establish safe conditions (Klüver et al., 2015).

Lethality is the inherent and potential ability of the toxic agent to cause harmful effects and death in living organisms. The toxic effect is generally proportional to the concentration of the toxic agent against the site of action (Klaassen \& Watkins, 2012).

The use of plant extracts has increased in aquaculture as an alternative for prophylactic control. The extracts have some advantages over synthetic products for the cultivation of aquatic organisms, such as, less toxicity because they are less concentrated; they have multiple modes of action, resulting in less likelihood of causing microbiota resistance; in addition to reducing the environmental impact, as these are biodegradable (no environmental pollution), helping in the quality of cultivation, and reducing production costs (Coimbra et al., 2006).

There are several medicinal plants that have potential to help aquaculture in this regard. For use with prophylactic purposes, it is essential to know the concentrations that may cause toxicity (chronic and lethal) to the organisms. Toxicity tests with herbal products aim the safety use of plant extracts without causing harmful effects to organisms kept in captivity (Claudiano et al., 2012; Aguinaga et al., 2014).

The bioactive compounds of plant extracts are substances that the plant synthesizes and stores during its growth. The active ingredients are not evenly distributed in the vegetable. They concentrate preferentially on flowers, leaves and roots, and sometimes on seeds, fruits and bark. These compounds are responsible for helping plants adapt to environments they are in, being sources of biologically active substances (Fumagali et al., 2008). In the plant extracts studied, flavonoids (phenolic compounds with activities such as antioxidant, anticancer, antibacterial, cardioprotective agents, anti-inflammation, immune system promoting, and so on) were analyzed, as they form a large group, due to the number of their natural constituents and wide distribution in the plant kingdom (Naczk \& Shahidi, 2006; Khan et al., 2014; Panche et al., 2016; Metodiewa et al., 2017; Tungmunnithum et al., 2018). Flavonoids can be found in diverse structural forms, but their fundamental nucleus has 15 carbon atoms that form a tricyclic compound (Zuanazzi \& Montanha, 2004). We believe in the relationship between the toxicity of plant extracts and their constitution in terms of flavonoids.

In order to test the different plant extracts from North of Brazil, we choose an important species of crustacean, the Macrobrachium amazonicum. This prawn is a Brazilian native species and can be found in the Amazon Basin, São Francisco Basin, Paraguay Basin, North and Northeast Coastal Basins, as well as countries like Guyana, French Guiana, Venezuela, Ecuador, Peru and Bolivia (Coelho \& Ramos-Porto, 1985; Pereira et al., 2017). It is also a species with great potential for aquaculture (New \& Valenti, 2000; Anjos et al., 2014). 
Social aspects are also relevant when it comes to M. amazonicum, because there are riverside populations that use species fishing as a means of survival in certain locations, such as "Pará" state, Brazil (Freire \& Bentes, 2008), where the activity generates jobs and income for families (Silva et al., 2017).

The objective of the present research was to use $M$. amazonicum, as a model to predict the toxicity of natural products (taking in consideration the flavonoids as bioactive compounds), for later use in aquaculture as aids in the treatment of animal diseases and organ disorders.

\section{Method}

The experiment was carried out with a completely randomized design with ten treatments (nine extracts and control) and three repetitions in each.

Herbal extracts containing tinctures from pariri, mairipuama, anauerá, barbatimão, faveira, sacaca, jacareúba, pau d'arco, and verônica were purchased from the Scientific and Technological Research Institute of Amapá (IEPA), in commercial packaging. The commercial samples obtained were sent to the mariculture sector of the Aquaculture Laboratory of the Federal University of Minas Gerais (UFMG) for the appropriate analysis and tests (ANVISA, 2010; Wannes et al., 2010).

Briefly, the content of total flavonoids was determined according to the methodology and determination equations described by Wannes et al. (2010), using aluminum chloride that reacts with the sample flavonoids generating a chromophore, which represents the characteristic molecule by identifying the characteristic yellow color of the flavonoids, which is evaluated at $420 \mathrm{~nm}$ in UV spectrophotometer. A calibration curve was plotted with rutin. The result was expressed in $\mathrm{mg}$ of rutin equivalents/g of extract. The validated parameters were linearity, specificity, precision, accuracy and robustness, as well as the determination of impurities and identification of the extract.

Ten post-larvae of $M$. amazonicum (Amazon river prawn) weighing $0.5 \pm 0.1 \mathrm{~g}$ were used per treatment, maintained in $500 \mathrm{~mL}$-beaker with aeration, containing the extracts under analysis. The concentrations tested were 1, 10, 100, 500 and $1000 \mu \mathrm{g} / \mathrm{mL}$ and were prepared in dimethyl sulfoxide (DMSO) and diluted in water, not exceeding 0.5\% DMSO in the final solution (Oliveira et al., 2019a).

After 24 hours, the dead prawns were removed. The tests with the nine extracts were performed in triplicates. Safety levels were defined based on the most estimated values for pollutants in relation to the median lethal concentration for $50 \%$ of the population ( $\mathrm{LC}_{50}$ ), multiplying the $\mathrm{LC}_{50}$ by the application factor proposed by Sprague (1971).

For the statistical tests, the Probit program (Finney, 1952) was used to estimate the $\mathrm{LC}_{50}$, and the Kruskal-Wallis test was used to determine the different toxicities between the extracts at the 5\% level of significance using the Infostat version 2019 program (Casanoves et al., 2012).

Regarding the study of total flavonoids for the different plant extracts, the results obtained are shown in the table 1. 


\section{Macrothink}

Journal of Agricultural Studies

ISSN 2166-0379

2021, Vol. 9, No. 2

\section{Results}

The $\mathrm{LC}_{50}-24 \mathrm{~h}$ of plant extracts for $M$. amazonicum post-larvae with the respective upper and lower limit values are shown in figure 1.

The extracts that had the greatest toxic effect were sacaca LC50-24h of $75.96 \mu \mathrm{g} / \mathrm{mL}$, faveira $\mathrm{LC}_{50}-24 \mathrm{~h}$ of $79.19 \mu \mathrm{g} / \mathrm{mL}$, and anauera $\mathrm{LC}_{50}-24 \mathrm{~h}$ was $99.94 \mu \mathrm{g} / \mathrm{mL}$.

Barbatimão and verônica showed the same toxicity to $M$. amazonicum post-larvae, the LC50-24h were $102.5 \mu \mathrm{g} / \mathrm{mL}$ (Tab. 2). The jacareúba showed $\mathrm{LC}_{50}-24 \mathrm{~h}$ of $322.2 \mu \mathrm{g} / \mathrm{mL}$, followed by pariri and muirapuama plants with the respective values of 433.3 and 493.9 $\mu \mathrm{g} / \mathrm{mL}$.

Based on the results obtained, the least toxic medicinal plant for Amazon river prawn was pau d'arco, with the $\mathrm{LC}_{50}-24 \mathrm{~h}$ of $722.2 \mu \mathrm{g} / \mathrm{mL}$. Table 2 . shows the safety levels of the tested extracts.

Table 1. Total concentration of flavonoids for the different plant extracts from Brazil

\begin{tabular}{lc} 
Extract & Total flavonoids ( mg/g \pm SD) \\
\hline Licania macrophylla & $9.65 \pm 0.25$ \\
Calophyllum brasiliense & $8.05 \pm 0.15$ \\
Veronica officinalis & $7.18 \pm 0.13$ \\
Vatairea guianensis & $6.33 \pm 0.80$ \\
Arrabidaea chica & $6.20 \pm 0.07$ \\
Croton cajucara & $6.00 \pm 0.83$ \\
Ouratea hexasperma & $2.59 \pm 0.14$ \\
Tabebuia sp. & N.D \\
Ptychopetalum olacoides & N.D \\
\hline
\end{tabular}

N.D $=$ no detected 


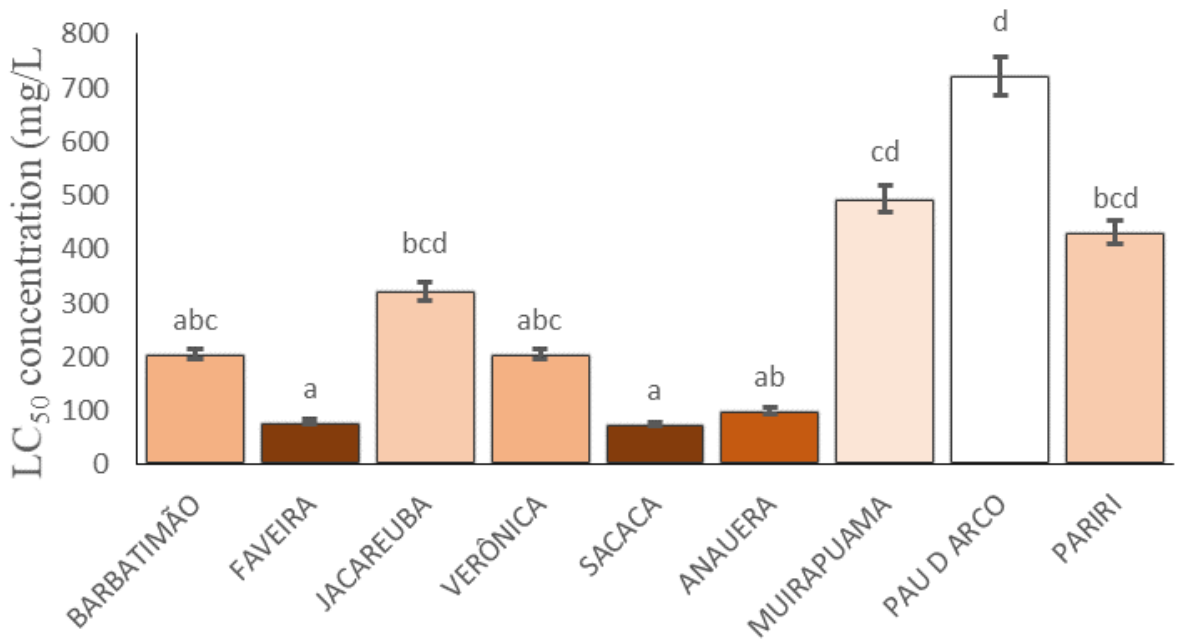

Plant extracts

Figure 1. Median lethal concentration $\left(\mathrm{LC}_{50}\right) 24 \mathrm{~h}$ of plant extracts to Amazon freshwater prawn Macrobrachium amazonicum. Different letters show significant differences $(\mathrm{P}<0.05)$ by the Kruskal Wallis test. Toxicity $a>b>c>d$.

Table 2. Safety levels for the use of Amazon plant extracts for freshwater prawn Macrobrachium amazonicum.

\begin{tabular}{cc}
\hline Plant Extract & Safety Level* $(\boldsymbol{\mu g} / \mathbf{m L}) \pm$ SD \\
Tabebuia sp. (Pau d'arco) & $72.22 \pm 3.62$ \\
Ptychopetalum olacoides (Muirapuama) & $49.39 \pm 2.48$ \\
Arrabidaea chica (Pariri) & $43.33 \pm 2.18$ \\
Calophyllum Brasiliense (Jacareúba) & $32.2 \pm 1.60$ \\
Veronica officinalis (Verônica) & $10.3 \pm 0.52$ \\
Ouratea hexasperma (Barbatimão) & $10.3 \pm 0.52$ \\
Licania macrophylla (Anauerá) & $10.0 \pm 0.50$ \\
Vatairea guianensis (Faveira) & $7.9 \pm 0.40$ \\
Croton cajucara (Sacaca) & $7.6 \pm 0.38$ \\
\hline *10\% LC 50 -24h.
\end{tabular}




\section{Discussion}

Regarding the study of flavonoids, some identifications for Licania were observed in a publication reporting the traditional, phytochemical, and pharmacological use of the genus (Feitosa et al., 2012). These authors described the chemical composition of several species of Licania, finding potential for flavonoids in some of them, such as Licania pettiere and $L$. carii. Additionally, Neto et al. (2013), conducted studies with Licania sp. and Parinari sp., showed more than six positive results for flavonoids. Medeiros \& Medeiros (2012) also discovered a new flavanol, licanol, in L. macrophylla. In the present study, a very favorable potential for flavonoids was identified in the species L. macrophylla, $9.65 \pm 0.25 \mathrm{mg} / \mathrm{g}$.

In a phytochemical approach performed on leaves of $A$. chica, Alves et al. (2008) reported the presence of different chemical classes, among them flavonoids. Our quantification of total flavonoids performed in this work identified $6.20 \pm 0.07 \mathrm{mg} / \mathrm{g}$ in A. chica.

Calophyllum brasiliense is a species of great medicinal interest in the treatment of diabetes, however in the literature there were no phytochemical studies related to flavonoids. In the present work, flavonoids were identified and quantified by spectrophotometry in the samples with a mean concentration of $8.05 \pm 0.15 \mathrm{mg} / \mathrm{g}$.

Ptychopetalum olacoides did not show potential for flavonoids in the analyzes performed in the present work. In the literature, no studies were found regarding the quantification of flavonoids performed with the species.

In a phytochemical study carried out with the bark of the $C$. cajucara tree, Tieppo et al. (2006) demonstrated the presence of several diterpene clerodanes such as trans-dehydrocrotonina, trans-crotonina, cis-cajucarina and sacacarina. Pharmacological analyses were performed with $C$. cajucara, and anti-inflammatory, antimicrobial, analgesic, antiulcerogenic or antilipemic properties were described. The bark essential oil has also been reported to have gastroprotective activity. According to Zou et al. (2013), a new flavonoid was found in $C$. cajucara, which represents a rare group of flavanols with specific cyclization. In the present study, the mean concentration of flavonoids for this species was $6.00 \pm 0.83 \mathrm{mg} / \mathrm{g}$.

There is no quantification of flavonoids in O. hexasperma in the literature. In the present study, the potential for flavonoids in that species showed a low result, with $2.59 \pm 0.14 \mathrm{mg} / \mathrm{g}$.

Veronica officinalis is a common species in the Amazon. (Nikolova, 2011), and studies were carried out regarding the identification of flavones in 29 species of Veronica and, in fact, found eight flavone aglycones. There are no comparative data regarding the quantification of flavonoids in $V$. officinalis in the literature. In the present study, one of the highest mean concentrations $(7.18 \pm 0.13 \mathrm{mg} / \mathrm{g})$ was identified in this species.

Vatairea guianensis presented few scientific references that mention biological activities for the species, as well as no data regarding flavonoids. Although Souza (2013) reported for the first time four isoflavones and five triterpenes identified in a lupeol mixture. The quantification of total flavonoids was $6.33 \pm 0.80 \mathrm{mg} / \mathrm{g}$ for $V$. guianensis.

Govindappa et al. (2013) in studies carried out regarding the antioxidant activity and 
phytochemical screening endophytes, noted that Tabebuia sp. proved to be a rich source of tannins, flavonoids, steroids, alkaloids, etc, especially phenolic and polyphenol. Such substances have been classified as cytotoxic, antimicrobial, and antifungal due to the presence of anthraquinone compounds. In our study, we did not identify total flavonoids in Tabebuia sp.

The study of flavonoids contained in plant extracts aims to quantify one of the main bioactive compounds that can cause intoxication in animals when used incorrectly. Although flavonoids are commonly found in plants for medicinal purposes, other bioactive compounds must be quantified in the extracts of the nine plants studied in the present study, in view of the additive effect of them on the biota treated with plant extracts.

Some crustaceans are widely used in ecotoxicological tests. Once the safety levels of plant extracts are defined to different animals, they can be used to treat them in closed cultivation systems without compromising their normal development. For this, it is also necessary to know their effectiveness in deal with specific pathogens.

Several toxicological studies are carried out with in small crustaceans observing some aspects such as mobility in Daphnia similis, reproduction in Ceriodaphnia dubia or lethality in $M$. amazonicum post-larvae (Oliveira-Filho, 2013).

Plant extracts may have antibacterial activity against pathogens that affect humans (Ushimaru et al., 2007) and animals (Dal Pozzo et al., 2011), and the replacement of current antimicrobials with herbal products in aquaculture is not utopia. Several medicinal plants have shown activity to control and prevent pathogenic bacteria in fish, such as Aeromonas hydrophila (Harikrishnan et al., 2009; Harikrishnan et al., 2010), Streptococcus iniae (Abutbul et al., 2004; Zilberg et al., 2010), Streptococcus agalactiae (Rattanachaikunsopon \& Phumkhachorn, 2010), Flavobacterium columnare (Tavechio et al., 2009), Pseudomonas fluorescens and Edwardsiella tarda (Harikrishnan et al., 2009).

These plant extracts can be of low cost to the producer and some are considered immunostimulants that increase the resistance of animals and stimulate non-specific responses of the immune system (Melo et al., 2008).

In an acute toxicological study carried out with Artemia salina exposed to three species of medicinal plants of the genus Phyllanthus, in Northeastern Brazil, the LC50-24h were similar to those found in this work for the species muirapuama, pau d'arco and pariri. The authors estimated the LC50-24h from $404.43 \pm 49.64$ to $770.84 \pm 51.78 \mu \mathrm{g} / \mathrm{mL}$ for Phyllanthus niruri, $837.65 \pm 61.45$ to $1,075.89 \pm 70.72 \mu \mathrm{g} / \mathrm{mL}$ for Phyllanthus amarus and $534.60 \pm 46.83$ $\mu \mathrm{g} / \mathrm{mL}$ to $1,003.62 \pm 65.15 \mu \mathrm{g} / \mathrm{mL}$ for Phyllanthus tenellus (Araujo et al., 2010).

The medicinal plant A. chica (pariri) is used as an anti-inflammatory, astringent, and against intestinal colic, diarrhea, anemia and skin diseases (Amaral et al., 2012). It presented low toxicity to M. amazonicum post-larvae, corroborating the study of Oliveira et al. (2009). These authors observed that this medicinal plant had practically no toxic effect on $M$. amazonicum post-larvae, demonstrating the low toxicity of the ethanolic extract present in the leaves. 
In addition, pariri also presented low toxicity to some mammals, as demonstrated in a study carried out with rats, whose median lethal dose $\left(L_{50}\right)=2 \mathrm{~g} / \mathrm{kg}$ (Oliveira et al., 2019b). Barbatimão, which is also used as an herbal medicine, should be administered with caution due to the phytotoxicity presented to animals such as Wistar rats (Rodrigues et al., 2013) and A. salina (Ramos et al., 2014).

Tests with A. salina exposed to ethanolic extract of Anauerá bark showed low toxicity to this small crustacean (Silva et al., 2011). In the same way, Faveira presented low toxicity for Wistar Rats, which can be used to treat integumentary tissue (Rodriguez et al., 2004). The use of trans-dehydrocrotonin from Sacaca in rats demonstrates a gastro-protective effect; however, at doses of $100 \mathrm{mg} / \mathrm{kg}$, this plant caused liver damage (Oliveira et al., 2014). The use of Jacareúba extract in rats above $1,000 \mathrm{mg} / \mathrm{kg}$ demonstrated deleterious effects and intoxication signals such as agitation and depression (Peters \& Guerra, 1995). Studies with verônica extract in pregnant rats did not caused embryo-toxicity and the authors indicate its use as an anti-inflammatory (Prósperi, 1993).

In general, $M$. amazonicum post-larvae are also important for monitoring the natural environments where the species occurs, as described in the literature (Silva, 2002; Costa et al., 2008; Pimentel et al., 2011; Hirota et al., 2012). Therefore, toxicity tests with prawn post-larvae are used in several research areas, such as aquaculture, medicinal chemistry, pharmacology, agriculture and ecotoxicity, the latter being of great importance in the evaluation of the toxic potential of extracts and isolated substances (Ikhwanuddin et al., 2014). Some authors have reported the effect of bioactive compounds from Brazilian plant extracts against bacteria (by antimicrobial activity) (Suffredini et al., 2004), favoring the raise of prawn M. amazonicum in captivity (Rocha et al., 2014; Brilhante et al., 2015).

In the present study, it was possible to verify the toxicity of plant extracts and their safety levels for use with Amazon prawn post-larvae. However, further work is needed to test its phytotherapic action (bioactive compounds) against pathogens, such as anti-inflammatories and other uses in the cultivation of M. amazonicum. The less toxic extracts (pau d'arco, pariri, muirapuama, and jacareúba) with anti-inflammatory and protective function of the organism can be used in the treatment of various disorders (Vicentino \& Menezes, 2007; Velasco et al., 2008; Carnevale-Neto et al., 2013; Carvalho et al., 2013). The other extracts (verônica, sacaca, barbatimão, anauerá, and faveira) must be used with greater care due to their toxic potential and has application as fungicides and bactericides in the systems and in treatments against these pathogens (Araújo, 2010; Lopes et al., 2012; Saha, 2013; Brasil, 2014; Rocha \& Galende, 2014).

\section{Conclusions}

The method carried out to flavonoid determination showed high specificity at $420 \mathrm{~nm}$ for the extracts of the species provided by the Institute of Scientific and Technological Research of Amapá (IEPA), giving reliability in the quantification of flavonoids.

Sacaca and faveira extracts were the most toxic to post-larvae of $M$. amazonicum, with the $\mathrm{LC}_{50}-24 \mathrm{~h}=72.16$ and $75.23 \mu \mathrm{g} / \mathrm{mL}$, respectively, and the least toxic medicinal plant was pau 
d'arco, with the $\mathrm{LC}_{50}-24 \mathrm{~h}=722.2 \mu \mathrm{g} / \mathrm{mL}$. The post-larvae of $M$. amazonicum showed sensitivity to the nine extracts evaluated, which predicts care in view of the toxic effects in the use of products derived from these plants if they are used in the cultivation of this crustacean.

The chemical diversity of the natural extracts encourages the study of other bioactive compounds (in addition to flavonoids) contained in the plant extracts tested. The research carried out with medicinal plants from the Amazon region was of paramount importance, in view of the plant richness of that region. Thus, the sequence of this research becomes important to assist the use of plant extracts in aquaculture.

\section{References}

Abutbul, S., Golan-Goldhirsh, A., Barazani, O., \& Zilberg, D. (2004). Use of Rosmarinus officinalis as a treatment against Streptococcus iniae in tilapia (Oreochromis sp.). Aquaculture, 238, 97-105. https://doi.org/10.1016/j.aquaculture.2004.05.016

Aguinaga, J. Y., Claudiano, G. S., Marcusso, P. F., Ikefuti, C., Ortega, G. G., Eto, S. F., ... Fernandes, J. B. K. (2014). Acute toxicity and determination of the active constituents of aqueous extract of Uncaria tomentosa Bark in Hyphessobrycon eques. Journal of Toxicology, 2014, 1-5. https://doi.org/10.1155/2014/412437

Albuquerque, U. P., \& Hanazaki, N. (2006). Ethnodirected research in the discovery of new drugs of medical and pharmaceutical interest: weaknesses and perspectives. Revista Brasileira de Farmacognosia, 16, 678-689. (in Portuguese). https://doi.org/10.1590/S0102-695X2006000500015.

Alves, M. S. M., Mendes, P. C., Vieira, J. G. P., Ozela, E. F., Barbosa, W. L. R., \& Silva-Júnior, J. O. C. (2008). Pharmacognostic analysis of Arrabidaea chica leaves (Humb. \& Bonpl.) B. Verlt., Bignoniaceae. Brazilian Journal of Pharmacognosia, 20, 215-221. (in Portuguese). https://doi.org/10.1590/S0102-695X2010000200013.

Amaral, R. R., Santos, A. A. D., Saravia, A., Botas, G., Cruz, R. A. S., Fernandes, C. P., Rocha, L., \& Boylan, F. (2012). Biological activities of Arrabidaea chica (Bonpl.) B. Verl. leaves. Latin American Journal of Pharmacy, 31, 451-455. http://www.latamjpharm.org/resumenes/31/3/LAJOP_31_3_1_15.pdf

Anjos, R. Q., Araújo, M. C., Nees, L. Q. S., Silva, T. N. S., Silva, R. F., \& Bastos, R. B. (2014). Different sources of carbohydrates in the Amazon shrimp diet (Macrobrachium amazonicum). In: Feira Nacional do Camarão, Fortaleza-CE, Brasil, Anais p. 25. (in Portuguese).

ANVISA - Agência Nacional de Vigilância Sanitária. (2010). Resolution-RDC no. 17 of April 16, 2010: Provides for Good Drug Manufacturing Practices. Brazil. (in Portuguese).

Araújo, N. R. R. (2010). In vitro evaluation of the antimicrobial activity of plant extracts on microorganisms related to oral mucositis lesions. Masters dissertation. UFPA. 100 p. (in Portuguese). 
BRASIL - Ministério da Saúde - Agência Nacional de Vigilância Sanitária. (2014). "Resolution rdc no 26, of May 13, 2014: Provides for the registration of herbal medicines and the registration and notification of traditional herbal products." ANVISA. 34 p. (in Portuguese).

Brilhante, R. S. M., Sales, J. A., Sampaio, C. M.S., Barbosa, F. G., Paiva, M. A. N., Guedes, G. M. M., ... Rocha, M. F. G. (2015). Vibrio spp. from Macrobrachium amazonicum prawn farming are inhibited by Moringa oleifera extracts. Asian Pacific Journal of Tropical Medicine, 8, 919-922. https://doi.org/10.1016/j.apjtm.2015.10.012

Carnevale-Neto, F. C., Pilon, A. C., Bolzani, V. S., \& Castro-Gamboa, I. (2013). Chrysobalanaceae: secondary metabolites, ethnopharmacology and pharmacological potential. Phytochemistry Reviews, 12, 121-146. (in Portuguese). http://dx.doi.org/10.1007/s11101-012-9259-z

Carvalho, H. O., Medeiros, B. J. L., Sá, B. M., Araújo, J. T. C., Kawakami, M. Y. M., Favacho, H. A. S., \& Carvalho, J. T. C. (2013). Study of the dissolution and disintegration of the capsules containing the dried hydroethanolic extract of Calophyllum brasiliense. Revista Brasileira de Farmacognosia, 23, 194-199. (in Portuguese). https://doi.org/10.1590/S0102-695X2012005000145

Casanoves, F., Balzarini, M. G., Di Rienzo, J. A., Gonzalez, L., Tablada, M., \& Robledo, C. W. (2012). InfoStat. User Manual, Córdoba, Argentina

Claudiano, G. S., Pilarski, F., Cruz, C., Salvador, R., Belo, M. A. A., \& Moraes, F. (2012). Lethal concentration $\mathrm{LC}_{50}$ of aqueous extract of Terminalia catappa leaves in Guaru, Phaloceros caudimacultus. Archives of Veterinary Science, 17, 1-5. (in Portuguese). http://ojs.c3sl.ufpr.br/ojs/index.php/veterinary/article/view/23168

Coelho, P. A., \& Ramos-Porto, M. (1985). Freshwater prawns in Brazil: geographical distribution. Revista Brasileira de Zoologia, 6, 405-410. (in Portuguese).

Coimbra, J. L., Soares, A. C. F., Garrido, M. S., Souza, C. S., \& Ribeiro, F. L. B. (2006). Toxicity of plant extracts to Scutellonema bradys. Pesquisa Agropecuária Brasileira, 41, 1209-1211. (in Portuguese). https://doi.org/10.1590/S0100-204X2006000700020

Costa, C. R., Olivi, P., Botta, C. M. R., \& Espindola, E. L. G. (2008). Toxicity in aquatic environments: discussion and evaluation methods. Quimica Nova, 31: 1820-1830. (in Portuguese). https://doi.org/10.1590/S0100-40422008000700038

Dal Pozzo, M., Viégas, J., Santurio. D. F., Rossatto, L., Soares, I. H., Alves, S. H., \& Costa. M. M. (2011). Antimicrobial activity of essential oils from condiments against Staphylococcus spp. isolates of goat mastitis. Ciência Rural, 41, 667-672. (in Portuguese). https://doi.org/10.1590/S0103-84782011005000029

Feitosa, E. A., Xavier, H. S., \& Randau, K. P. (2012). Chrysobalanaceae: traditional uses, phytochemistry and pharmacology. Brazilian Journal of Pharmacognosia, 22, 1181-1186. https://doi.org/10.1590/S0102-695X2012005000080 
Finney, D. J., Ed. (1952). Probit Analysis. Cambridge, England, Cambridge University Press.

Freire, J. L., \& Bentes, B. S. (2008). Socio-environmental aspects of freshwater shrimp fisheries (Macrobrachium amazonicum Heller, 1862 and Macrobrachium rosenbergii De Man, 1879) (Decapoda, Palaemonidae) in Northeast Pará. Boletim do Laboratório de Hidrobiologia, 21, 51-62. (in Portuguese).

Fumagali, E., Gonçalves, R. A. C., Machado, M. F. S., Vidoti, G. J., \& Oliveira, A. J. B. (2008). Production of secondary metabolites in plant cell and tissue culture: the example of the genera Tabernaemontana and Aspidosperma. Brazilian Journal of Pharmacognosia, 18, 627-641. (in Portuguese). https://doi.org/10.1590/S0102-695X2008000400022

Govindappa, M., Channabasava, R., Kumar, K. S., \& Pushpalatha, K. C. (2013). Antioxidant activity and phytochemical screening of crude endophytes extracts of Tabebuia argentea Bur. \& K. Sch. American Journal of Plant Science, 4, https://doi.org/1641-1652.10.4236/ajps.2013.48198

Harikrishnan, R., Balasundaram, C., \& Heo, M. S. (2009). Effect of chemotherapy, vaccines and immunostimulants on innate immunity of goldfish infected with Aeromonas hydrophila. Diseases on Aquatic Organisms, 88, 45-54. https://doi.org/10.3354/dao02143

Harikrishnan, R., Balasundaram, C., \& Heo, M. S. (2010). Potential use of probiotic and triherbal extractenriched diets to control Aeromonas hydrophila infection in carp. Diseases on Aquatic Organisms, 92, 41-49. https://doi.org/10.3354/dao02240

Hirota, B. C. K., Paula, C. S., Miguel, O. G., \& Miguel, M. D. (2012). In vitro toxicity assessment: applicability of the lethality test against the Artemia salina. Visão Acadêmica, 13, 42-48. (in Portuguese). http://dx.doi.org/10.5380/acd.v13i2.27834

Ikhwanuddin, M., Moh, V. H. Z., Hidayah, M., Norr-Hidayati, A. B., Aina-Lyana, N. M. A., \& Juneta, A. S. N. (2014). Effect of Indian almond, Terminalia cattapa leaves water extract on the survival rate and growth performance of black tiger shrimp, Penaeus monodon post larvae. AACL Bioflux, 7, 85-93. http://www.bioflux.com.ro/docs/2014.85-93.pdf

Khan, N., Al-Daghri, N. M., Al-Ajlan, A. S., \& Alokail, M. S. (2014). The use of natural and derived sources of flavonoids and antioxidants in Saudi Arabia. Integrated Food Nutrition and Metabolism, 1, 100-106. https://doi.org/10.15761/IFNM.1000109

Klaassen, C. D., \& Watkins III, J. B. (2012). Fundamentals in toxicology of Casarett e Doul. $2^{\text {nd }}$ ed. Porto Alegre: AMGH, 472 p. (in Portuguese).

Klüver, N., König, M., Ortmann, J., Massei, R., Paschke, A., Kühne, R., \& Scholz, S. (2015). Embryo toxicity test: Identification of compounds with weak toxicity and analysis of behavioral effects to improve prediction of acute toxicity for neurotoxic compounds. Environmental Science and Technology, 49, 7002-7011.

https://pubs.acs.org/doi/10.1021/acs.est.5b01910

Lopes, L. C., Medeiros, F. A., \& Medeiros, A. A. N. (2012). Chemical study of species leaves Licania macrophila Benth (Chrysobalanaceae). Revista de Pesquisa e Iniciação Científica, 
2012, 4-6. (in Portuguese).

Medeiros, F. A., \& Medeiros, A. A. N. (2012). Licanol, a new flavanol and other constituents from the Licania macrophylla Benth. Química Nova, 35, 1179-1183. (in Portuguese). https://doi.org/10.1590/S0100-40422012000600021

Melo, J. E., Lima e Silva, T. C., Veras-Filho, J., Santos, E. M., Albuquerque, U. P., \& Amorim, E. L. C. (2008). Phytochemical study and toxicological bioassay against larvae of Artemia salina Leach. of three medicinal species of the genus Phyllanthus (Phyllanthaceae). Revista de Ciências Farmaceuticas Básica e Aplicada, 92, 145-150. (in Portuguese).

Metodiewa, D., Kochman, A., \& Karolczak, S. (1997). Evidence forantiradical and antioxidant properties of four biologically active $\mathrm{N}$, diethylaminoethyl ethers offlavanone oximes: a comparison with natural polyphenolicflavonoid (rutin) action. Biochemical and Molecular Biology International, 41, 1067-1075.

https://doi.org/10.1080/15216549700202141.

Naczk, M., \& Shahidi, F. (2006). Phenolics in cereals, fruits, and vegetables: Occurrence, extraction and analysis. Journal of Pharmaceutical and Biomedical Analysis, 41, 1523-1542. https://doi.org/10.1016/j.jpba.2006.04.002.

Neto, F. C., Pilon, A. C., Bolzani, V. S, \& Castro-Gamboa, I. (2013). Chrysobalanaceae: secondary metabolites, ethnopharmacology and pharmacological potential. Phytochemistry Reviews, 12, 121-146. http://dx.doi.org/10.1007/s11101-012-9259-z

New, M. B., \& Valenti, W. C. (2000). Freshwater Prawn Culture: The farming of Macrobrachium rosenbergii. Oxford: Blackwell Science Ltd. 443 p.

Nikolova, M. (2011). Screening of radical scavenging activity and polyphenol content of Bulgarian plant species. Pharmacognosy Research, 3, 256-259. 10.4103/0974-8490.89746 10.4103/0974-8490.89746

Oliveira, D. P. C, Borrás, M. R. L., \& Ferreira, L. C. L. (2009). Aqueous extract of Arrabidaea chica (Humb. \& Borigenpl.) Revista Brasileira de Farmacognosia, 19, 643-649. (in Portuguese).

Oliveira, F. P., Fernandes, H. J., Rial, A. A. L. S., \& Soutello RVG. (2019a). Dimethylulphoxide (DMSO) and activity of two extracts of Magonia pubescens on Rhipicephalus (Boophilus) microplus. Brazilian Journal of Development, 5, 23724-23736. (in portuguese). ttps://doi.org/10.34117/bjdv5n11-075

Oliveira, M. C, Lemos, L. M. S., Oliveira, R. G., Dall’Oglio, E. L., Souza-Jr, P. T., \& Martins, D. T. O. (2014). Evaluation of toxicity of Calophyllum Brasiliense steam bark extract by in vivo and in vitro assays. Journal of Ethnopharmacology, 155, 30-38. https://doi.org/10.1016/j.jep.2014.06.019

Oliveira, P. A., Fidelis, Q. C., Fernandes, T. F. C., Souza, M. C., Coutinho, D. M., Prudêncio, E. R., Castro, R. N., Riger, C. J., Carvalho, M. G., \& Marinho, B.G. (2019b). Evaluation in vivo and in vitro of antioxidant, antinociceptive, and anti-inflammatory activities of 
biflavonoids from Ouratea hexasperma and O. ferruginea. Natural Products Communication, 2019, 1-7. https://doi.org/10.1177/1934578X19856802

Oliveira-Filho, E. C. (2013). Chapter 8: toxicity assessment. In: Sisinno, C. L. S; Oliveira-Filho, E. C. "Principles of environmental toxicology. Interciência: Rio de Janeiro, 216 p. (in Portuguese).

Panche, A. N., Diwan, A. D., \& Chandra, S. R. (2016). Flavonoids: an overview. Journal of Nutrition Science, 5, 1-15. https://doi.org/10.1017/jns.2016.41

Pereira, J. A., Castro, P. M., Costa, F. Z., \& Santos, M. A. L. (2017). Freshwater prawns (Crustacea: Decapoda) that occur in the Água Boa stream, municipalities of Alto Alegre e Boa Vista, Roraima. Boletim do Museu Integrado de Roraima, 2, 39-44. (in Portuguese).

Peters, W. M., \& Guerra, M. O. (1995). Effects of Dalbergia subcymosa Ducke decoction on rats and their offspring during pregnancy. Journal of Ethnopharmacology, 46, 161-165. https://doi.org/10.1016/0378-8741(95)01244-8

Pimentel, M. F., Silva-Junior, F. C. G., Santaella, S. T., \& Lotufo, L. V. C. (2011). The use of Artemia sp. as a test organism for assessing the toxicity of wastewater from cashew processing before and after treatment in an experimental biological reactor. Journal of Braziliam Society of Ecotoxicology, 6, 15-22. (in Portuguese). https://doi.org/10.5132/jbse.2011.01.003

Prósperi, V. A. (1993). Application of toxicity tests with marine organisms for the analysis of industrial effluents discharged in estuarine areas. Doctoral thesis. Universidade de São Paulo-USP. 128 p. (in Portuguese).

Ramos, R. S., Rodrigues, A. B. L., \& Almeida, S. S. M. S. (2014). Preliminary study of the extract of the barks of Licania macrophyla Benth: Phytochemicals and toxicological aspects. Biota Amazonica, 4, 94-99. http://dx.doi.org/10.18561/2179-5746/biotaamazonia.v4n1p94-99

Rattanachaikunsopon, P., \& Phumkhachorn, P. (2010). Use of Asiatic pennywort Centella asiatica aqueous extract as a bath treatment to control columnaris in Nile tilapia. Journal of Aquatic Animals Health, 22, 14-20. https://doi.org/10.1577/H09-021.1

Rocha, A. G., \& Galende, S. D. (2014). The importance of quality control in the pharmaceutical industry. UNINGÁ, 20, 97-103. (in Portuguese).

Rocha, M. F. G., Alencar, L. P., Brilhante, R. S. M., Sales, J. A., Ponte, Y. B., Rodrigues, P. H. A., Sampaio, C. M. S., Cordeiro, R. A., Castelo-Branco, D. S. C. M., Oliveira, F. C., Barbosa, F. G., Teixeira, C. E. C., Paiva, M. A. N., Bandeira, T. J.P. G., Moreira, J. L. B., \& Sidrim, J. J. C. (2014). Moringa oleifera inhibits growth of Candida spp. and Hortaea werneckii isolated from Macrobrachium amazonicum prawn farming with a wide margin of safety. Ciência Rural, 44, 2197-2203. https://doi.org/10.1590/0103-8478cr20140266

Rodrigues, D. F., Mendes, F. F., Feitosa, A. D., Silva, J. A., \& Silva, L. A. F. (2013). Barbatimão bark extract, Stryphnodendron adstringens (Martius) Coville, in wound healing in animals. Enciclopédia Biosfera, 9, 1583-1601. (in Portuguese). 
http://repositorio.bc.ufg.br/tede/handle/ri/13256

Rodriguez, J. A., Hiruma-Lima, C., \& Brito, A. R. M. S. (2004). Antiulcer activity and subacute toxicity of trans-dehydrocrotonin from Croton cajucara. Human and Experimental Toxicology, 23, 455-461. https://doi.org/10.1191/0960327104ht473oa

Saha, S., Shilpi, J. A., Mondal, H., Hossain, F., Amazzman, M., Haissan, M. D. M., \& Cordell, G. A. (2013). Ethnomedicinal, phytochemical, and pharmacological profile of the genus Dalburgia L. (Fabaceae). Phytopharmacology, 4, 291-346.

Silva, A. C. (2002). Treatment of the landfill leachate and assessment of the toxicity of the raw and treated effluent. Masters dissertation, COPPE/Universidade Federal do Rio de Janeiro-UFRJ. 126 p. (in Portuguese).

Silva, C. T. C., Medeiros, B. J. S., Santos, K. C., Pereira-Filho. R., Albuquerque, R. L. C., Souza, P. J. C., \& Carvalho, J. T. C. (2011). Topical healing activity of the hydroethanolic extract from seeds of Vatairea guianensis (Aublet). International Journal of Pharmaceutical Sciences Review and Research, 8, 1-8.

Silva, F. N. L., Silva, F. R., Mangas, T. P., Oliveira, L. C, Macedo, A. R. G., Medeiros, L. R, \& Cordeiro, C. A. M. (2017). The trade in Amazonian shrimp (Macrobrachium amazonicum) in the city of Breves - Pará - Brasil. PubVet, 4, 320-326. (in Portuguese). https://doi.org/10.22256/PUBVET.V11N4.320

Souza, C. V. (2013). Effect of plant regulators on the development of young plants of Tabebuia avellanedae Lorentz ex Griseb. Course completion work (bachelor's degree Biological Sciences). Universidade Estadual Paulista, UNESP, Instituto de Biociências de Botucatu, Botucatu-SP. (in portuguese).

Sprague, J. B. (1971). Measurement of pollutant toxicity to fish. III. Sublethal effects and safe concentrations, Water Research, 5, 245-266.

https://doi.org/10.1016/0043-1354(71)90171-0

Suffredini, I. B., Sader, H. S., Gonçalves, A. G., Reis, A. O., Gales, A. C., Varella, A. D., \& Younes, R. N. (2004). Screening of antibacterial extracts from plants native to the Brazilian Amazon Rain Forest and Atlantic Forest. Brazilian Journal of Medical and Biological Research, 37, 379-384. https://doi.org/10.1590/S0100-879X2004000300015

Tavechio, W. L. G., Guidelli, G., \& Portz, L. (2009). Alternatives for the prevention and control of pathogens in fish farming. Boletim do Instituto de Pesca, 35, 335-341. (in Portuguese). https://www.pesca.agricultura.sp.gov.br/boletim/index.php/bip/article/view/864

Tieppo, M., Porawski, M., Salvador, M., Moreira, A. J., Collado, P. S., González-Gallego, J., \& Marroni, N. P. (2006). Croton cajucara Benth leaf extract scavenges the stable free radical DPPH and protects against oxidative stress induced by paraquat. Biology and Pharmacology Bulletin, 29, 161-165. https://doi.org/10.1248/bpb.29.161

Tungmunnithum, D., Thongboonyou, A., Pholboon, A., \& Yangsabai, A. (2018). Flavonoids and other phenolic compounds from medicinal plants for pharmaceutical and medical aspects: 
an overview. Medicines, 5, 1-16. https://doi.org/10.3390/medicines5030093

Ushimaru, P. K, Silva, M. T. N., Di, S. C., Barbosa, L., \& Fernandes-Junior, A. (2007). Antibacterial activity of medicinal plant extracts. Brazilian Journal of Microbiology, 38, 717-719. https://doi.org/10.1590/S1517-83822000000400003

Velasco, M. V. R., Maciel, C. P. M., Samuf, F. D., Pinto. C. A. S. O., Consilieri, V. O., Kaneko. T. M., \& Baby, A. R. (2008). Development and preliminary test of the stability of cosmetic formulations plus commercial extract of Trichilia catigua Adr. Juss (e) Ptychopetalum olacoides Bentham. Revista de Ciências Farmaceuticas Basica e Aplicada, 29, 181-196. (in Portuguese).

Vicentino, A. R. R., \& Menezes, F. D. S. (2007). Antioxidant activity of vegetable tinctures sold in pharmacies DPPH methodology. Revista Brasileira de Farmacognósia, 17: 384-387. (in Portuguese). https://doi.org/10.1590/S0102-695X2007000300014

Wannes, W. A., Mhamdi, B., Sriti, J., Jemia, M. B., Ouchikh, O., Hamdaoui, G., Kchouk, M. E., \& Marzouk, B. (2010). Antioxidant activities of the essential oils and methanol extracts from myrtle (Myrtus communis var. italica L.) leaf, stem and flower. Food Chemistry and Toxicology, 48, 1362-1370. https://doi.org/10.1016/j.fct.2010.03.002

Zilberg, D., Tal, A., Froyman, N., Abutbul, S., Dudai, N., \& Golan-Goldhirsh, A. (2010). Dried leaves of Rosmarinus officinalis as a treatment for streptococcosis in tilapia. Journal of Fish Disease, 33, 361-369. https://doi.org/10.1111/j.1365-2761.2009.01129.x

Zou, K., Teng, J., Huang. L., Dai, X., \& Wei, B. (2013). Effect of osmotic pretreatment on quality of mango chips by explosion puffing drying. Food Science and Technology, 51, 253-259. https://doi.org/10.1016/j.1wt.2012.11.005

Zuanazzi, J. Â. S., \& Montanha, J. A. (2004). Flavonoids. In: Simões, C. M. O. et al.: Pharmacognosy from Plant to Drug. $5^{\text {th }}$ ed. Florianópolis: Editora da Universidade Federal de Santa Catarina; Porto Alegre: Editora da Universidade Federal do Rio Grande do Sul-UFRGS. p. 577-614. (in portuguese).

\section{Copyright Disclaimer}

Copyright for this article is retained by the author(s), with first publication rights granted to the journal.

This is an open-access article distributed under the terms and conditions of the Creative Commons Attribution license (http://creativecommons.org/licenses/by/4.0/). 